\title{
A Multivariate Causal Model of Alumni Giving: Implications for Alumni Fundraisers
}

Received (in revised form): October 29, 2007

\section{Xiaogeng Sun}

earned a Ph.D. in educational studies from the University of Nebraska-Lincoln. He is the Assistant Director of Program Evaluation in the Anchorage School District, Alaska.

\section{Sharon C. Hoffman}

is a Ph.D. candidate at the University of Nebraska-Lincoln in educational leadership. Her research interests are in leadership theory and developing organizational strategic capacity.

\section{Marilyn L. Grady}

earned a Ph.D. and is Professor of Educational Administration at the University of NebraskaLincoln. Her research interests are in leadership theory, leader preparation, and advocacy.

\section{Abstract \\ Despite readily available alumni survey data warehoused at many alumni associations and foundations across colleges and universities, researchers have underutilized the abundant available data to identify key predictors of alumni donation, including factors that trigger alumni donation behavior. Utilizing the data from a two-year alumni survey conducted at a Midwest public university, a multivariate causal model that captures the determinants of alumni donation was applied to the data. Four hypotheses were tested. Three were found to be significant.}

\footnotetext{
Author's Contact Address:

Xiaogeng Sun

Anchorage School District

5530 E. Northern Lights Blvd.

Anchorage AK 99504, USA

Phone: +1 9077430599

Fax: +1 9077430599

Email: Sun_Xiaogeng@asdk12.org
}

Based on a multivariate causal model that analyzed data from a two-year alumni survey, the findings suggest that alumni fundraisers and higher education administrators may increase alumni solicitations if they collaboratively create a comprehensive communication strategy to reach alumni; focus on current students as future funders, provide quality educational experiences to students; encourage and support relationship building between faculty and current students and graduates; enhance alumni services based on stakeholders needs; and most importantly, redirect and expand efforts to connect with older female alumni.

International Journal of Educational Advancement (2007) 7, 307-332. doi:10.1057/palgrave.ijea.2150073

Keywords:

alumni giving, communication strategy, fund raising 


\section{Introduction}

US higher education institutions improved fund-raising results overall in 2006, a 9.4 percent or $\$ 2.4$ billion increase from $2005 .^{1}$ This was the largest increase since 2000 , due to larger single donation amounts from alumni and others. What did not increase, however, was the number of alumni donors. Even though alumni donations improved 18.35 percent, the number of alumni donors remained flat, or slightly decreased by 0.02 percent (Strout, 2007a, p. A1).

Alumni fundraisers are discovering that their efforts compete more than ever before with larger athletic departments as they vie for donations. In 1998, athletic gifts accounted for 14.7 percent of all contributions. By 2003, alumni and other donor contributions to sports accounted for 26 percent of all donations (Wolverton, 2007, p. A1).

Given the static number of alumni contributors and the competition for alumni dollars, the results of this study have important implications for higher educational institutions, and alumni associations in particular. If university administrators and alumni fundraisers prioritize fund-raising strategies and expenditures, these efforts may result in more cost-effective approaches with increased alumni contributions.

The purpose of this study was to investigate the impact of student experience, alumni experience, alumni motivation, and demographic variables associated with alumni on alumni giving.

\section{Alumni-Giving Decision Model}

The researchers proposed the alumnigiving decision model featured in Figure 1.

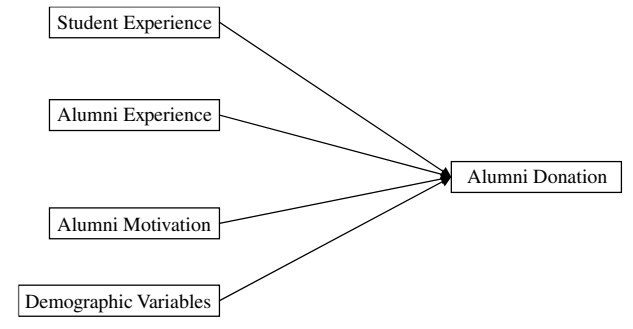

Figure 1: Alumni-giving decision model

\section{Student experience}

An argument exists that alumni who were treated favorably as students, who were satisfied with their academic experiences, and who believe their college education contributed to their career success are more inclined to give as alumni than those with less favorable feelings and beliefs.

\section{Alumni experience Alumni experience is alumni perceptions of their interactions with their alma maters after graduation. Alumni experience can be perceived as marketing efforts of the alumni association because most alumni interact with the alma mater through the alumni association.}

\section{Alumni motivation}

The research results indicated that alumni motivation to give was significantly related to actual giving (Gardner, 1975; Beeler, 1982; Oglesby, 1991; Halfpenny, 1999; Clotfelter, 2003). Motivation is defined as an internal state or desire that serves to activate behavior (Kleinginna and Kleinginna, 1981). Alumni motivation is the internal desire that is rooted deeply enough in one's awareness to induce a desire to give to the alma mater. 


\section{Demographic variables}

Specific demographic variables have been found to be significantly related to alumni giving. According to Bristol (1990), the number of years between graduation and onset of giving had a substantial effect on the magnitude of alumni giving. The participation rate in alumni donation rises with the increase of class age. Research by Graham and Husted (1993) demonstrated a high correlation between alumni wealth and their donations to the alma mater.

\section{General Hypotheses}

The following research hypotheses were proposed in this study.

\section{Hypothesis 1: Student experience} significantly distinguishes alumni donors from nondonors.

Hypothesis 2: Alumni experience significantly distinguishes alumni donors from nondonors.

Hypothesis 3: Alumni motivation significantly distinguishes alumni donors from nondonors.

Hypothesis 4: Demographic variables (graduation year, gender, ethnicity, type of degree, in or out of state, membership status) significantly distinguish alumni donors from nondonors.

\section{Delimitations and limitations}

One delimitation applies to this study. The study was based on the experiences reported by alumni at one
Midwest university on the survey data in each of two years: 2001 and 2002.

\section{Limitations}

The following limitations were identified for the study:

1. This research assumes the sample to be as representative of the population as possible. Sampling errors, however, may not provide an extensive picture of the experiences of the study population.

2. Because the data collection method was a self-report survey, respondents may have compromised their responses and provided socially desirable answers.

3. Responses to questions related to student experience and alumni experience may also be susceptible because of the reliance on the memories, biases, prejudices, and perspectives of respondents.

4. Self-selection of the respondents resulted in a greater number of alumni donor participants in this survey than alumni nondonors.

5 . The survey data were collected after September 11, 2001. This tragic event may have influenced the donation behavior of American citizens. No attempt, due to data constraints, was made to adjust for this limitation.

\section{Significance of the study}

The results of this study are important for several reasons. First, through examination of the findings, alumni fundraisers may improve their ability to distinguish alumni donors from nondonors and target likely donors in their fund-raising efforts. Alumni fund raising may improve with reliable approaches to identifying potential donors from nondonors. 
Secondly, fund raising is generally regarded as relationship marketing. Alumni who believe or feel they are well treated are more inclined to give than alumni without similar beliefs or feelings. The results may identify several alumni services that alumni deem important but the alumni association may not adequately provide. The study's results may help the alumni association identify improved services in order to increase alumni satisfaction and subsequent giving.

Finally, the results may enrich the body of alumni research by specifically targeting alumni at a Midwest, public, research-extensive university. Other higher education institutions may fine tune this model according to their specific situations and identify important determinants of alumni giving.

\section{Theoretical Frameworks on Charitable Giving}

Research development on charitable giving in general, and alumni giving in particular, is attributable to the theoretical and conceptual frameworks proposed by both economists and sociologists. Some of the most prominent economic frameworks are proposed by Becker (1974), Sugden (1984), Andreoni (1989, 1990), and Steinberg (1997). Among sociologists, important theories are proposed by Thibaut and Kelley (1959), Blumer (1969), Walster and Walster (1978), Foa and Foa (1974), and Bar-Tal (1976).

\section{Neoclassical microeconomic theories on charitable giving} Neoclassical microeconomic theory makes the following three assumptions
(Weintraub, 1985).

1.Individuals have preferences for outcomes.

2. Utility was maximized by individuals.

3. Individuals act independently based on full and relevant information.

\section{Public good theory}

In public good theory, the purpose of charitable donations is the collective interest of the donors and donees. The donor gains utility from the total utility out of donations from all donors, and not from an individual recipient's additional utility.

\section{Social exchange theory}

Halfpenny (1999) maintains that some common statements from the social exchange theory pertain to the donation process. First, the social exchange theory focuses on the human interaction during social exchange. An exchange occurs only when both parties in the exchange find their rewards attractive. The question "Why do donors give money and time to others without rewards?" provides opportunity for exploration. One explanation is that a reward is obvious to the giver, but not obvious to the observer.

\section{Equity theory}

The equity theory (Walster and Walster, 1978) assumes that society rewards individuals for equity in their interactions with others. The significance of the equity theory lies in the feeling of distress that derives from inequitable relationships. Greater understanding of individuals' donation decisions is more likely if there is greater knowledge about how individuals perceive rewards and 
distress in a donation process

(Halfpenny, 1999).

\section{Symbolic interactionism}

Symbolic interactionism (Blumer, 1969) asserts that individuals get the meaning about the world through interaction with the surrounding environment. Symbolic interactionism, when applied to the donation process, suggests that through interaction with the social and physical environment, individuals assume or reject the role of donor or donee (Halfpenny, 1999).

\section{Supply and demand analysis of alumni giving}

Yoo and Harrison (1989) applied supply and demand analysis to alumni giving and claimed that it seems more logical to deem donors as conventional buyers who purchase some services from donees. Therefore, Yoo and Harrison (1989) suggested using the average amount of donation per donor as the price donors pay for the services they receive from their alma mater.

Donors derive utility from the services provided by the recipients. The reciprocity between the donor and donee may be in the form of honors and alumni services. Yoo and Harrison (1989) also asserted that donors should be regarded as buyers who receive tangible and intangible benefits from the recipients. They classified gifts as one form of market exchange in which both donors and donees are motivated by self-interest.

\section{Organizational theories on alumni giving}

Mael and Ashforth (1992) applied Organizational Identity Theory (OID) to the study of alumni giving. Organizational identification is defined as a perception that one belongs to an organization and shares the success and failure of the organization. According to the social identity theory, the self-concept is characterized by a personal identity that includes characteristics such as abilities and interests, and a social identity that includes group classification. The social identity theory predicts that individuals tend to participate in activities that match their social identities and support the institutions representing these identities. The researchers considered alumni giving a possible outcome of organizational identification (Mael and Ashforth, 1992).

\section{Other theories on alumni giving} Coelho (1985) suggests that the need for status is the motivation for donations because the need to seek status explains many actions. Alumni donations may be alternative sources of funding for public goods. Halfpenny (1999) suggests that unconstrained donations create wealth: the value as a charitable giving to a donee exceeds the value kept for the donor's own use. Winston (1999) argues that universities are nonprofit; therefore, they must acquire alternative funding from donations.

Donative revenues can be considered an indicator of the institution's education performance: alumni who donate are recognizing the role that the institution played in their education. Burt (1989) indicates that donation might be understood as a measure of the quality of education. Alumni giving also depends on the 
alumni association's effectiveness in solicitations. Clotfelter (2003) found that donations to private universities are higher than those to the public universities.

\section{Empirical Studies on Alumni Giving}

\section{Demographic variables}

A body of literature of particular interest to college presidents and alumni fundraisers focuses on the characteristics of alumni. Olsen et al. (1989) tested a lifecycle hypothesis of alumni giving at a small liberal arts college. They found that the growth rate of donations is related to the ageincome profile of donors. In a similar age-donation profile of more than 4,000 alumni of a large public university, Okunade et al. (1994) estimated that growth rates of alumni donations decline after age 52, short of retirement age. They also found larger donations from business school graduates, members of non-Greek social organizations. Grimes and Chressanthis (1994) studied the effect of intercollegiate athletics on alumni donation at a Division I NCAA school and found that a winning season and television appearances are related to higher alumni giving.

\section{Other research on the} demographics of alumni donors Taylor and Martin (1995) investigated selected attitudinal, demographic, involvement, and philanthropic characteristics of alumni donors and nondonors from a Research I, public university. The authors used a 32-item self-reporting survey instrument for data collection.
Six variables were found to be discriminators of donors/nondonors: family income, need for financial support, reading alumni publications, enrollment for graduate work, special interest group, and involvement with university as an alumnus/a.

Bruggink and Siddiqui (1995) built a model based on the characteristics of the alumni at an independent liberal arts college. With this model, they intended to identify factors that influence giving. The dependent variable was the amount of alumni giving during the fiscal year. The independent variables included income, age, marriage, Greek, year, and employment status. Bruggink and Siddiqui (1995) reported that income, Greek status, alumni activity, distance from the alma mater, years after graduation, marital status, and alumni's major were statistically significant.

Hueston (1992) used a logistic regression framework to analyze 34,938 alumni case files at New Mexico State University. Roughly 16 percent of the high alumni donor group graduated from the business school.

Lindahl and Winship (1992) built a model for fund-raising analysis at Northwestern University based on 2,803 alumni data sets and logit model regression estimates. They found past giving history, year of donation, religious beliefs, and salary levels to be significant predictors of alumni donation.

Okunade et al. (1994) used covariance regression and a 1975/76$1989 / 90$ data sample to analyze the donation of undergraduate alumni of Memphis State University who graduated in the 1926/27-1975/76 period. They found that business school alumni, alumni who later earned a 
graduate degree at the same university, and alumni members of non-Greek social clubs made more donations than other alumni. Giving was also found to vary over business cycles.

Okunade and Berl (1997) used a logit regression model to analyze the survey response data from the 1955/56-1990/91 alumni of a public, Research I university. The time since graduation, major, willingness to recommend the university, household attributes, family ties to the alma mater, and the availability of matching gift accounts were found to be significant factors of alumni donations.

With data sets from two public universities in the United Kingdom, Belfield and Beney (2000) examined the predictors of alumni giving. Using ordinary least square techniques, they estimated two models for both the probability of giving and the total amount given. They found gender effects to be statistically significant. Females were found to have a higher propensity to give than males. Belfield and Beney (2000) also found that those who are married have a lower probability to give. The elasticity of amount given with respect to income is estimated at $0.2085-0.5534$. Their finding supported Okunade and Berl's (1997) study that alumni giving increased with age but at a decreasing rate.

\section{Economic variables}

In Harrison's (1995) study, use of the parameters was based on the particular sample and historical period of observations. He emphasized that it would not be useful to use these coefficients to predict a particular school's outcome from future alumni relations expenditures. Each school needs to build its own model.

\section{Other research}

Leslie et al. (1983) studied the charitable donations to higher education as an aggregate from 1932 to 1974 . Charitable contributions to higher education as an aggregate were found to be significantly related to business environments. Leslie also found opposite effects of economic conditions on personal and corporate donations. Leslie et al. (1983) concluded that personal giving will rise when economic conditions are poor and higher education institutions are most in need of donation, while corporate giving will increase with good economic conditions.

\section{Motivation variables}

Some studies have explored the influence of motivation on alumni donations. Miracle (1977) indicated that alumni who recognize the financial needs of the alma mater would be more motivated to give than those without similar perceptions.

\section{Alumni experience}

Numerous studies focused on the relationship between postgraduate alumni activities and alumni donations. Shadoian (1989) used several variables related to alumni experience in his alumni donation model. Number of postgraduate campus visits, reading alumni publications, and contacts with faculty members were found to be significant predictors of future donation.

Miracle's (1977) study results were somewhat different from those of Shadoian's. He did not find number 
of campus visits after graduation to be an important predictor; however, postgraduate involvement with the university was a significant factor in determining alumni donation. Oglesby's (1991) results confirmed the significance of postgraduate involvement with the university as a predictor of alumni giving.

Oglesby (1991) also examined the influence of spouse donation. He concluded that spouse contribution to an alma mater was not a significant variable. He suggested that another variable, supporting other charitable causes, was significant.

\section{Methodology and Procedures}

\section{Research design}

For this study, a nonexperimental, applied research design and data from a two-year alumni satisfaction survey were utilized to investigate the impact of student experience, alumni experience, alumni motivation, and demographic variables on alumni giving.

\section{Hypotheses}

To address the purpose of this study, the following hypotheses were proposed:

\section{Hypothesis 1: Student experience} significantly distinguishes alumni donors from nondonors.

Hypothesis 2: Alumni experience significantly distinguishes alumni donors from nondonors.

Hypothesis 3: Alumni motivation significantly distinguishes alumni donors from nondonors.
Hypothesis 4: Demographic variables (graduation year, gender, ethnicity, type of degree, in or out of state, membership status) significantly distinguish alumni donors from nondonors.

\section{Site}

The study's site was a Midwest, public, Research Extensive university. Officially chartered in 1869 , this university was one of the nation's leading state universities. At the time of the study, the university offered 149 undergraduate majors and 116 graduate degree programs and had 23,000 students enrolled in classes. The university had 175,000 alumni residing in the United States and around the world. Among them, 25,000 alumni email addresses were listed in the database.

\section{Instrument}

The instrument used in this study was a proprietary survey designed cooperatively by Performance Enhancement Group and alumni association officials from 12 public and private universities. They worked in a series of focus group studies to discuss the items to be included in the survey. The survey sought responses to questions about four areas of the alumni experience: overall experience, loyalty, student experience, and alumni experience. A fifth area asked for specific demographic information.

The instrument, administered annually since 2001, retains and implements most items to enhance the longitudinal integrity of the instrument. In any year, additional items may be added to reflect new 
inputs from participating alumni associations. All variables included in this study were present in both 2001 and 2002 surveys.

\section{Population and sample}

The population for this study was 175,000 alumni of the Midwest university. The alumni association first used simple random sampling to select respondents. The Performance

Enhancement Group then adjusted the sample to expand its representation. The final set of selected respondents included 5,960 alumni in 2001 and 5,499 alumni in 2002. In the end, 1,030 alumni completed the 2001 survey and 724 alumni completed the 2002 survey. The response rate was 24 and 18 percent for 2001 and 2002, respectively.

\section{Variable selection}

\section{Criterion variable}

Responses to one survey question served as the criterion variable: "Which of the following best describes your financial support of the university?" Five choices were available to the respondents:

1. Have never financially supported the university and do not plan to in the future ("never/do not plan to").

2. Have financially supported the university but do not plan to continue ("donated/won't continue").

3. Have never financially supported the university but plan to in the future ("never/but plan to").

4. Currently financially support the university and plan to continue ("donated/plan to continue").
5. Currently financially support the university and plan to increase in the future (donated/plan to increase).

According to their responses, alumni were divided into five groups: "never/ do not plan to," “donated/won't continue," "never/but plan to," "donated/will continue," and "donated/will increase." The intent of the research was to determine what predictors, if any, can explain membership in the five groups.

\section{Predictor variables}

According to Stevens (2002), the number of predictors is a crucial factor that determines how well a given equation will generalize. Generally, an $n / k$ ratio ( $n=$ sample size and $k=$ predictors) of 15 is needed for a reliable equation. In the original survey, there were 71 questions. This number raised concerns that too many predictors might decrease the predictive power of the model. Furthermore, several questions referred to the same or similar constructs. This is viewed as a multicollinearity problem, that is, there are moderate to high intercorrelations among the predictors.

A preliminary correlation matrix was constructed in order to examine correlations and determine whether multicollinearity existed. When a large number of explanatory variables present such a multicollinearity problem, the relative contributions of some variables are clouded. The data did, in fact, exhibit a strong linear relationship among a number of the survey items. Because of the presence of the multicollinearity problem, data reduction through factor analysis was used. 
Table 1: Factor loadings

Factor 1 Factor 2 Factor 3 Factor 4 Factor 5

\begin{tabular}{clc}
\hline Factor 1 & & \\
Q17BP_1 & Quality of alumni association website & $0.708^{\mathrm{a}}$ \\
Q17HP_1 & $\begin{array}{l}\text { Quality of communication regarding } \\
\text { your services/benefits }\end{array}$ & $0.702^{\mathrm{a}}$ \\
& \\
Q17DP_1 & Quality of electronic newsletter & $0.678^{\mathrm{a}}$ \\
Q17AP_1 & Quality of monthly bulletins & $0.638^{\mathrm{a}}$ \\
Q17CP_1 & Quality of university website & $0.633^{\mathrm{a}}$ \\
Q17 IP_1 & Quality of invitations to university activities & $0.624^{\mathrm{a}}$ \\
Q17GP_1 & Quality of email & $0.622^{\mathrm{a}}$ \\
Q17EP_1 & Quality of reunion mailings & $0.592^{\mathrm{a}}$ \\
Q17 JP_1 & Quality of alumni magazine & $0.591^{\mathrm{a}}$ \\
Q17FP_1 & Quality of alumni staff presentations & $0.528^{\mathrm{a}}$
\end{tabular}

Factor 2

Q08 II_1 How important is it for alumni to provide

$0.752^{\mathrm{a}}$ leadership by serving on boards.

Q08HI_1 How important it is for alumni to volunteer for the university

Q08 JI_1 How important it is for alumni to attend events

Q08 EI_1 How important it is for alumni to serve as ambassadors

Q08GI_1 How important it is for alumni to network with other alumni

Q08DI_1 How important it is for alumni to recruit students

Q08FI_1 How important it is for alumni to provide financial support for the university

Q08CI_1 How important it is to provide feedback about community perceptions

Q08AI_1 How important it is for alumni to mentor students?

Factor 3

Q07B_1

Q07C_1

Q07E_1

Q07F_1

Q07A_1

Q07D_1

Commitment to continuous learning

Responding to new career opportunities

Deepening my understanding and

commitment to personal development

Further graduate education

Current work status

Contributing to my community

Factor 4

Q10MP_1 What I learned about life $\quad 0.721^{\mathrm{a}}$

Q10NP_1 Exposure to new things $\quad 0.717^{\mathrm{a}}$

Q10BP_1 Relationships with other students $\quad 0.651^{\mathrm{a}}$

Q10OP_1 Traditions or values learned on campus $\quad 0.626^{\mathrm{a}}$

Q10DP_1 Relationships with faculty $\quad 0.613^{\mathrm{a}}$

Q10CP_1 Academics classes $\quad 0.584^{\mathrm{a}}$

Q10JP_1 Relationships with administrators and staff $\quad 0.488^{\mathrm{a}}$ 
Table 1: Continued.

Factor 1 Factor 2 Factor 3 Factor 4 Factor 5

\begin{tabular}{clc}
\hline Factor 5 & & $0.707^{\mathrm{a}}$ \\
Q10KP_1 & Student leadership opportunities & $0.641^{\mathrm{a}}$ \\
Q10HP_1 & Participation in fraternity/sorority & $0.464^{\mathrm{a}}$ \\
Q10FP_1 & Attending cultural events & $0.424^{\mathrm{a}}$ \\
Q10EP_1 & Attending athletic events & . \\
\hline
\end{tabular}

atem with the highest factor loadings.

\section{Factor analysis}

In the factor analysis, five factors were extracted based on the following rationale.

The list of items included in the factor analysis is displayed in Table 1. The number and content of higher loading survey items included in each factor are also presented.

Factor 1-named alumni experiencecontained ten survey items. Five items that come with the highest loadings were:

- Please tell us the quality/usefulness of alumni association monthly bulletins.

- Please tell us the quality/usefulness of alumni association communication regarding your membership.

- Please tell us the quality/usefulness of alumni association electronic newsletters.

- Please tell us the quality/usefulness of university website.

- Please tell us the quality/usefulness of invitations to university activities.

Most of the survey items were related to alumni satisfaction with the services and information provided by the alumni association. This inclusion is consistent with previous research that concluded that alumni experience is a significant predictor of alumni donation (Oglesby, 1991).
Factor 2-named alumni motivationincluded nine survey items. Items with the highest loading were:

- In your opinion, how important is each of the following alumni activities to the university: providing leadership by serving on boards, committees, etc?

- In your opinion, how important is each of the following alumni activities to the university: volunteering for the university?

- In your opinion, how important is each of the following alumni activities to the university: attending events?

- In your opinion, how important is each of the following alumni activities to the university: serving as an ambassador for the university?

- In your opinion, how important is each of the following alumni activities to the university: networking with other alumni?

These survey items were linked with alumni motivations to support the university, which corresponds to the alumni motivation in the decision model.

Factor 3-named student experienceimpact on career because these survey items were closely linked with student experience and how alumni appreciate 
the contribution of college education to their future careers-included six survey items. Items with the highest loading were:

- How well did the highest degree from the university prepare you for commitment to continuous learning?

- How well did the highest degree from the university prepare you for responding to new career opportunities?

- How well did the highest degree from the university prepare you for deepening understanding and commitment to personal development?

- How well did the highest degree from the university prepare you for further graduate education?

Factor 4-named student experiencerelationships-included seven survey items. The survey items of student experience are closely related to the alumni experience, especially relationships with others while they were students. Items with the highest loading were:

- How did what you learned about life (on campus) affect your student experience?

- How did exposure to new things (on campus) affect your student experience?

- How did attending athletic events affect your student experience?

- How did relationships with other students affect your student experience?

- How did relationships with faculty affect your student experience?

Factor 5-named student experienceextracurricular activities-is closely related to six survey items. These items are clearly connected with the alumni experience of extracurricular activities while they were students. Items with the highest loading were:

- How did student leadership opportunities affect your student experience?

- How did participation in fraternity/ sorority affect your student experience?

- How did attending culture events affect your student experience?

- How did attending athletic events affect your student experience?

- How did orientation for new students affect your student experience?

A pictorial summary of factor and factor names is displayed in Table 2.

\section{Statistical technique}

Discriminant analysis was used to identify the important predictors of alumni giving and to assess the usefulness of the predictive model. Discriminant analysis is used for two proposes: (a) to statistically reveal differences among different groups of the criterion variable and (b) to

Table 2: Factors and factor names

\begin{tabular}{|c|c|c|}
\hline & Factor & Factor name \\
\hline $\mathrm{F} 1$ & Factor 1 & Alumni experience \\
\hline $\mathrm{F} 2$ & Factor 2 & Alumni motivation \\
\hline F3 & Factor 3 & $\begin{array}{l}\text { Student experience-impact on } \\
\text { career }\end{array}$ \\
\hline F4 & Factor 4 & $\begin{array}{l}\text { Student experience- } \\
\text { relationships }\end{array}$ \\
\hline F5 & Factor 5 & $\begin{array}{l}\text { Student experience- } \\
\text { extracurricular activities }\end{array}$ \\
\hline
\end{tabular}


classify respondents into different groups based on predictor variables (Stevens, 2002).

Discriminant analysis has two features: “(a) parsimony of description and (b) clarity of interpretations" (Stevens, 2002, p. 286). The discriminant analysis is parsimonious because predictor variables can be linearly combined to form a less discriminant function. In this study, there were 11 predictor variables, and the criterion variable had five different groups ("never/do not plan to," "donated/won't continue," "never/but plan to," "donated/will continue," and "donated/will increase"). In the end, one may only find that these five groups differ mainly on two dimensions. That is, only two significant discriminant functions explain the difference among different groups. Discriminant analysis is also straightforward to interpret in that these functions are uncorrelated. Each discriminant function only reveals one dimension, that is, one reason, to explain the difference among different groups of the criterion variable.

\section{Data analysis}

The purpose of this study was to determine whether or not quantitative support existed for the multivariate alumni decision model, that is, whether the predictors specified in the model significantly distinguished donors from nondonors. This question was addressed by considering whether the variables measured in the surveys were jointly related to distinguishing donors from nondonors.

In order to address the collinearity problem, that is, too many predictors that were highly correlated, a factor analysis was applied to produce data reduction. As a result of the factor analysis, 33 items were excluded from the factor analysis because of low factor loadings. The remaining 38 items generated five factors described earlier. These five factors also corresponded to the alumni-giving decision model.

In the second step, after predictor variables were identified and classified as factors, the discriminant analysis was used as the primary method to assess the significance of each predictor variable in the model. Survey item 21 was appointed the criterion variable and had five levels of response. Table 3 displays the criterion variable and predictor variables included in the discriminant analysis.

The discriminant analysis equation assessed the significance of the predictors to correct classification of alumni into degrees of donor or nondonor groups. "The researcher can conclude whether or not the collection of predictors correctly classified individuals into groups and which of the variables contribute significantly to the prediction of group membership" (Stevens, 2002, p. 286).

\section{Analysis Results}

\section{Introduction of the data analysis} SPSS for Windows 13.0 software was used for the analysis. The data analysis involved three steps:

First, factor analysis generated five factors. These five factors, together with other demographic variables supported by previous research, were used as predictors in the follow-up discriminant analysis. 
Table 3: List of predictors in the discriminant analysis

\begin{tabular}{|c|c|}
\hline Variables & Origination of variable \\
\hline \multicolumn{2}{|l|}{ Criterion variable } \\
\hline \multirow[t]{5}{*}{ Donation status } & Survey item \#21-Choice 1 "never/do not plan to" \\
\hline & Survey item \#21—Choice 2 “donated/won't continue” \\
\hline & Survey item \#21-Choice 3 “never/but plan to" \\
\hline & Survey item \#21—choice 4 "donated/plan to continue" \\
\hline & Survey item \#21-Choice 5 "donated/plan to increase" \\
\hline \multicolumn{2}{|l|}{ Predictor variables } \\
\hline F1 Alumni experience & Generated from factor analysis \\
\hline F2 Alumni motivation & Generated from factor analysis \\
\hline F3 Impact on career & Generated from factor analysis \\
\hline F4 Relationship & Generated from factor analysis \\
\hline F5 Extracurricular & Generated from factor analysis \\
\hline Type of degree & Survey item: Degree obtained from the alma mater: undergraduate/graduate \\
\hline Graduation year & Survey item: The year that the alumnus/a graduated \\
\hline Gender & Survey item: Gender of the alumnus/a \\
\hline Ethnicity & Survey item: Ethnicity of the alumnus/a \\
\hline $\begin{array}{l}\text { Membership status by } \\
\text { respondent }\end{array}$ & Survey item: Whether the alumnus/a is a member of the alumni association \\
\hline In or out of state & Survey item: Whether the alumnus/a is residing in state or out of state \\
\hline
\end{tabular}

Secondly, discriminant analysis was used to analyze the differences among five alumni groups and to identify important predictors distinguishing these groups. Discriminant analysis generated the linear combination of the predictors that maximally separated five alumni groups.

Thirdly, the predictive ability of the discriminant function model, or the success of this model in correctly classifying alumni into their specific groups, was tested. The results of these three steps are briefly described below.

\section{Factor analysis results}

In the factor analysis, 33 survey items were excluded because of their low factor loadings. The remaining 38 survey items were reduced to five factors. These five factors have been described in the methodology section.

\section{Discriminant analysis results} Among the four discriminant functions generated by discriminant analysis, only the first two functions were statistically significant. The first discriminant function was identified as the dimension that maximally separates Group 3 "never/but plan to" and Group 4 "donated/will continue." The second significant function was interpreted as the dimension that maximally separates Group 1 "never/do not plan to" and Group 5 “donated/will increase."

In identifying significant predictors, graduation year and gender were identified as significant predictors of the first discriminant function that maximally separates Group 3 "never/ but plan to" and Group 4 "donated/ will continue." That is, the differences between these two groups can be 
mainly explained by the graduation year and gender variables.

Alumni motivation, alumni experience, student experiencerelationships, and student experienceextracurricular activities were identified as significant predictors of the second discriminant function, which maximally separates Group 1 "never/ do not plan to" and Group 5 "donated/will increase."

\section{Classification of alumni results}

The other function of discriminant analysis is to classify alumni into different groups. For example, if an alumnus/a answered in the survey that he/she never donated before and will not donate in the future, he belongs to Group 1 "never/do not plan to" in this study. Discriminant analysis, based on the prediction of 11 predictor variables, will also assign the alumnus/a to one of the five alumni groups. If discriminant analysis predicted that the alumnus/a was in Group 1 and his/her actual response matches this placement, this would be called a correct classification. The percent of alumni correctly classified are often called hit rate. The percent of alumni correctly classified in each of the five alumni groups is presented in Table 4.

Overall, 56.3 percent of the alumni were correctly classified. This model performed well at classifying alumni into Group 4 "donated/will continue" (81 percent correctly classified) and Group 5 "donated/will increase" (80.2 percent correctly classified).

\section{Description of output statistics and diagnostics}

\section{Assumption test}

As stated earlier, caution should be used when the assumptions of discriminant analysis, especially the assumption of equal variance, are violated. Box's $M$ tested the assumption of equality of variancecovariance across groups. If this test was significant, the equal variance assumption of discriminant analysis was violated.

The Box's $M$ test (see Table 5) was significant and indicated that the variances-covariances were not equal among the five alumni groups. The inequality of variance indicated that each alumni group had a different standard deviation on the predictor variables. The inequality of covariance suggested that the correlation between every two alumni groups was different among these five alumni groups. Since this assumption is violated, a separate variance-covariance matrix for each alumni group was used.

\section{Significant test of discriminant functions}

In this study, there were 11 predictor variables, and the criterion variable had five groups ("never/do not plan to," "donated/won't continue," "never/but plan to," "donated/will continue," and "donated/will increase"). According to the rule stated earlier, discriminant analysis can generate up to four discriminant functions. Eigenvalue Table (Table 6) and Wilk's Lambda Table (Table 7) assessed the significance and correlations of these four discriminant functions. The discriminant analysis procedure provided the eigenvalue, displayed in Table 6, and Wilks' Lambda, displayed in Table 7, for assessing how well the discriminant model as a whole fit the data.

The Eigenvalue Table provided information about the usefulness of 
Table 4: Classification results

\begin{tabular}{|c|c|c|c|c|c|c|}
\hline \multirow[b]{2}{*}{$\begin{array}{l}\text { Best describe your financial } \\
\text { participation }\end{array}$} & \multicolumn{5}{|c|}{ Predicted group membership } & \multirow[b]{2}{*}{ Total } \\
\hline & $\begin{array}{l}1 \\
\text { Never/do } \\
\text { not plan to }\end{array}$ & $\begin{array}{l}2 \\
\text { Have/do } \\
\text { not plan to }\end{array}$ & $\begin{array}{l}3 \\
\text { Never/but } \\
\text { plan to }\end{array}$ & $\begin{array}{l}4 \\
\text { Currently/ } \\
\text { plan to } \\
\text { continue }\end{array}$ & $\begin{array}{l}5 \\
\text { Currently/ } \\
\text { plan to } \\
\text { increase }\end{array}$ & \\
\hline \multicolumn{7}{|l|}{ Original count } \\
\hline 1. Never/do not plan to & 21 & 0 & 69 & 93 & 0 & 183 \\
\hline 2. Have/do not plan to & 8 & 0 & 24 & 108 & 0 & 140 \\
\hline 3. Never/but plan to & 12 & 0 & 241 & 175 & 2 & 430 \\
\hline 4. Currently/plan to continue & 18 & 0 & 121 & 723 & 1 & 863 \\
\hline 5. Currently/plan to increase & 0 & 0 & 25 & 111 & 2 & 138 \\
\hline \multicolumn{7}{|l|}{ Original \% } \\
\hline 1. Never/do not plan to & 11.5 & 0 & 37.7 & 50.8 & 0 & 100 \\
\hline 2. Have/do not plan to & 5.7 & 0 & 17.1 & 77.1 & 0 & 100 \\
\hline 3. Never/but plan to & 2.8 & 0 & 56 & 40.7 & 0.5 & 100 \\
\hline 4. Currently/plan to continue & 2.1 & 0 & 14 & $83.8 *$ & 0.1 & 100 \\
\hline 5. Currently/plan to increase & 0 & 0 & 18.1 & $80.4^{*}$ & 1.4 & 100 \\
\hline \multicolumn{7}{|l|}{ Cross-validated count } \\
\hline 1. Never/do not plan to & 20 & 0 & 70 & 93 & 0 & 183 \\
\hline 2. Have/do not plan to & 8 & 0 & 24 & 108 & 0 & 140 \\
\hline 3. Never/but plan to & 14 & 0 & 231 & 183 & 2 & 430 \\
\hline 4. Currently/plan to continue & 18 & 0 & 127 & 717 & 1 & 863 \\
\hline 5. Currently/plan to increase & 0 & 0 & 25 & 112 & 1 & 138 \\
\hline \multicolumn{7}{|l|}{ Cross-validated $\%$} \\
\hline 1. Never/do not plan to & 10.9 & 0 & 387.3 & 50.8 & 0 & 100 \\
\hline 2. Have/do not plan to & 5.7 & 0 & 17.1 & 77.1 & 0 & 100 \\
\hline 3. Never/but plan to & 3.3 & 0 & 53.7 & 42.6 & 0.5 & 100 \\
\hline 4. Currently/plan to continue & 2.1 & 0 & 14.7 & $83.1 *$ & 0.1 & 100 \\
\hline 5. Currently/plan to increase & 0 & 0 & 18.1 & $81.2 *$ & 0.7 & 100 \\
\hline
\end{tabular}

*Alumni groups with highest rate of correct clarification.

Table 5: Box's $M$ test results

\begin{tabular}{|c|c|c|}
\hline Box’s M & & 919.706 \\
\hline$F$ & Approx. & 3.399 \\
\hline d.f.1 & & 264 \\
\hline d.f. 2 & & 734811.552 \\
\hline Sig. & & $0.000^{\mathrm{a}}$ \\
\hline
\end{tabular}

${ }^{\mathrm{a} A l p h a}<0.05$.

each discriminant function. The eigenvalue is equivalent to a Pearson's correlation between the discriminant scores and the groups. The information in Table 6 makes it clear that, although four discriminant functions was calculated by computer automatically, nearly all of the variance explained by the model were due to the first two discriminant functions (96.6 percent of the variance explained). SPSS still calculated Function 3 and Function 4, but due to their low eigenvalues, these two functions were ignored.

Wilks' Lambda Table (Table 7) assessed the significance of the four discriminant functions and the result 
Table 6: Eigenvalue

\begin{tabular}{lllll}
\hline Function & Eigenvalue & $\begin{array}{l}\text { \% of variance } \\
\text { explained }\end{array}$ & $\begin{array}{l}\text { Cumulative \% variance } \\
\text { explained }\end{array}$ & Canonical correlation \\
\hline 1 & 0.199 & 65.8 & 65.8 & 0.407 \\
2 & 0.093 & 30.8 & $96.6^{\mathrm{a}}$ & 0.292 \\
3 & 0.007 & 2.2 & 98.8 & 0.082 \\
4 & 0.004 & 1.2 & 100 & 0.059 \\
\hline
\end{tabular}

${ }^{a}$ First two functions explained $96.6 \%$ of the total variance.

Table 7: Wilks’ Lambda

\begin{tabular}{llrll}
\hline $\begin{array}{l}\text { Test of } \\
\text { function(s) }\end{array}$ & $\begin{array}{l}\text { Wilks' } \\
\text { Lambda }\end{array}$ & Chi-square & d.f. & Sig. \\
\hline 1 through 4 & 0.755 & 448.431 & 44 & $0.000^{*}$ \\
2 through 4 & 0.906 & 158.658 & 30 & $0.000^{*}$ \\
3 through 4 & 0.99 & 16.406 & 18 & 0.564 \\
4 & 0.996 & 5.631 & 8 & 0.688 \\
\hline
\end{tabular}

"Significant when alpha was set at $<0.05$.

corroborated the finding from the Eigenvalue Table. Wilk's Lambda is a measure of how well each function separates individual alumnus/alumnae into different alumni groups. It is equal to the proportion of the total variance in the discriminant scores not explained by differences among the groups. Smaller values of Wilks' Lambda indicate greater discriminatory ability of the function. Wilks' Lambda agreed that only the first two functions were useful. The test of Function 3 and Function 4 had a significance value greater than 0.10 , and so these functions contributed little to the model.

The associated chi-square statistic (Table 7) tested the null hypothesis that the means of the functions listed were equal across groups. The small significance value indicated that the discriminant function did better than chance at separating the groups. Only the first two discriminant functions were significant at the $p<0.05$ level.
These data further confirmed that only the first two functions are significant functions that separate five alumni groups.

\section{Interpretation of significant discriminant functions}

Since the first two discriminant functions were significant, the next question is: how do we interpret these two discriminant functions, that is, linear combinations of predictor variables? Table of Group Centroids (Table 8) helps in understanding the dimension that is associated with each discriminant function. A centroid is the mean of discriminant scores generated by the discriminant function in each alumni group.

Table of Group Centroids (Table 8) displays the mean of discriminant scores by each alumni group. For example, in the first discriminant function, the mean discriminant score (centroid) for the "never/but plan to" group was 0.619 and the mean discriminant score (centroid) for the "donated/will continue" group was -0.371 . The distance between the centroids of these two alumni groups was the greatest. Therefore, the first discriminant function mainly separates Group 3 and Group 4. That is, alumni in Group 3, "never/but plan to," and Group 4, "donate/will continue," mainly differ on the first discriminant function (dimension). 
Table 8: Function at group centroids

\begin{tabular}{|c|c|c|c|c|}
\hline \multirow{2}{*}{$\begin{array}{l}\text { Best describe your financial } \\
\text { participation }\end{array}$} & \multicolumn{4}{|l|}{ Function } \\
\hline & 1 & 2 & 3 & 4 \\
\hline 1. Never/do not plan to & 0.534 & $-0.583^{\mathrm{a}}$ & -0.086 & -0.095 \\
\hline 2. Donated/won't continue & -0.032 & -0.422 & -0.095 & 0.177 \\
\hline 3. Never/but plan to & $0.619^{b}$ & 0.247 & 0.049 & 0.018 \\
\hline 4. Donated/will continue & $-0.371^{b}$ & -0.034 & 0.043 & -0.012 \\
\hline 5. Donated/will increase & -0.274 & $0.598^{\mathrm{a}}$ & -0.218 & -0.027 \\
\hline
\end{tabular}

${ }^{\mathrm{a} G r o u p ~} 1$ and Group 5 maximally separated at Function 2.

${ }^{\mathrm{b}}$ Group 3 and Group 4 maximally separated at Function 1.

In the second discriminant function, the mean discriminant score (centroid) for Group 1, "never/do not plan to," was -0.583 and the mean discriminant score (centroid) for Group 5 , “donated/will increase," was 0.598 . The distance between these two centroids was the greatest, and the second discriminant function was the dimension that explains the difference between Group 1 and Group 5. Since the third and fourth discriminant functions were not statistically significant, they were not analyzed for centroid effect.

Assessment of the significance of each predictor variable

The interest was in identifying significant predictor variables of alumni donation. The identification of significant predictors was a two-step process. In the first step, the analysis of Variance (ANOVA) technique was used to explore the significance of each predictor variable at differentiating different alumni groups. The ANOVA technique identified seven predictor variables as significant predictors of alumni donation.

In the second step, seven significant predictor variables identified in the first step were analyzed by discriminant analysis to determine which predictor variables had the highest correlation with the significant discriminant functions. Discriminant analysis already identified the first two discriminant functions as significant functions. Among the seven significant predictor variables identified in the ANOVA tests, only those predictors that had the highest correlations with the first or the second discriminant functions were identified as significant predictors.

\section{ANOVA test}

The result of ANOVA test was revealed in the Table of Equality of Group Means (Table 9). This table assessed a variable's potential in differentiating alumni groups. Each test displayed the result of a one-way ANOVA for the predictor variable using the criterion variable as the factor. If the significance value was greater than a $p$-value of 0.05 , the variable probably did not contribute to the model.

Graduation year, gender, alumni experience, alumni motivation, student experience-impact on career, and student experience-relationships were significant at the 0.00 level. Student 
Table 9: Tests of equality of group means

\begin{tabular}{llllll}
\hline & $\begin{array}{l}\text { Wilks' } \\
\text { Lambda }\end{array}$ & $F$ & d.f.1 & d.f.2 & Sig. \\
\hline F1 Alumni experience & 0.969 & 12.878 & 4 & 1603 & $0.000^{* *}$ \\
F2 Alumni motivation & 0.965 & 14.326 & 4 & 1603 & $0.000^{* * *}$ \\
F3 Student experience-impact on career & 0.976 & 10.037 & 4 & 1603 & $0.000^{* * *}$ \\
F4 Student experience-relationships & 0.986 & 5.813 & 4 & 1603 & $0.000^{* * *}$ \\
F5 Student experience-extracurricular activities & 0.994 & 2.598 & 4 & 1603 & $0.035^{*}$ \\
Graduation year & $0.856^{* * *}$ & 67.206 & 4 & 1603 & $0.000^{* *}$ \\
Type of degree & 0.996 & 1.568 & 4 & 1603 & 0.180 \\
Gender & 0.984 & 6.454 & 4 & 1603 & $0.000^{* *}$ \\
Ethnicity & 0.992 & 3.221 & 4 & 1603 & $0.012^{*}$ \\
Membership status by respondent & 0.998 & 0.977 & 4 & 1603 & 0.419 \\
In or out of state from respondent filing & 0.997 & 1.372 & 4 & 1603 & 0.241
\end{tabular}

*Significant at 0.05 level.

**Significant at 0.00 level.

$\because *$ Lowest $\lambda$ value.

experience-extracurricular activities and ethnicity were significant at the $p=0.05$ level. Types of degree, membership status, and in or out of state status are not significant at the $p=0.05$ level.

Wilks' Lambda for predictors (Table 7) is another measure of a predictor's potential. Smaller values indicate that the variable is better at discriminating different groups. The analysis suggests that graduation year is the best predictor of the model $(\lambda=0.856)$, followed by alumni experience, alumni motivation, student experience-impact on career, student experience-relationships, and gender.

\section{Discriminant analysis of significant} predictor variables

In this step, seven significant predictor variables identified by ANOVA were further analyzed by discriminant analysis. The structure matrix (Table 10) provided the correlation of each predictor variable with each of the discriminant functions. When more than one discriminant function exists, letter "a" in the table marks each variable's largest absolute correlation with one of the discriminant functions. Within each function, these marked variables are then ordered by the size of the correlation.

Among the seven significant predictors identified by ANOVA, graduation year is most strongly correlated with the first function, followed by the gender variable. These two variables are the only two significant variables with the first function. Thus, the differences between Group 3 "never/but plan to" and Group 4 "donated/will continue" are mainly accounted for by two variables: graduation year and gender.

Among the seven significant predictor variables, alumni motivation, alumni experience, student experiencerelationships, and student experienceextracurricular activities have the highest correlations with the second discriminant function. As stated previously, the second discriminant function mainly explained the differences between Group 1 
Table 10: Structure matrix

\begin{tabular}{lcrrr}
\hline Predictors & Function & & & \\
\cline { 2 - 5 } & 1 & 2 & 3 & 4 \\
\hline Graduation year & $0.863^{\mathrm{a}}$ & 0.461 & -0.106 & 0.039 \\
Gender & $0.278^{\mathrm{a}}$ & 0.072 & 0.195 & 0.022 \\
Alumni motivation & -0.275 & $0.466^{\mathrm{a}}$ & -0.047 & 0.357 \\
Student experience-relationships & 0.008 & $0.386^{\mathrm{a}}$ & 0.258 & -0.211 \\
Student experience-extracurricular activities & -0.002 & $0.261^{\mathrm{a}}$ & -0.148 & -0.005 \\
Ethnicity & 0.173 & -0.017 & 0.533 & 0.204 \\
Student experience-impact on career & -0.261 & 0.327 & $0.428^{\mathrm{a}}$ & 0.289 \\
Type of degree & -0.071 & -0.003 & -0.457 & $0.653^{\mathrm{a}}$ \\
Alumni experience & -0.296 & $0.388^{\mathrm{a}}$ & -0.177 & $-0.389^{\mathrm{a}}$ \\
In or out of state & -0.12 & 0.044 & 0.023 & -0.332 \\
Membership status & -0.069 & 0.107 & -0.105 & -0.315 \\
\hline
\end{tabular}

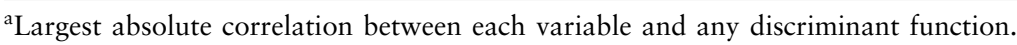

"never/do not plan to" and Group 5

"donated/will increase." The

differences between these two

groups were mostly explained by alumni experience, student experiencerelationships, student experienceextracurricular activities, and alumni motivation.

Student experience-impact on career and ethnicity were closely related to the third discriminant function, while types of degree and in/out of state status are closely related to the fourth function. But these two are almost useless functions since they do not explain much of the differences among the five alumni groups. Therefore, at the end of discriminant analysis, six predictor variables were identified as significant predictors of alumni donation: Graduation year, gender, alumni experience, alumni motivation, student experience-extracurricular activities, and student experiencerelationships.

Prediction using discriminant analysis Discriminant analysis is also used for prediction and classification. The classification table (Table 4) shows the practical results of using the discriminant model. Discriminant analysis used this model to classify alumni into different groups.

As the "Original\%" section in Table 4 indicated, of the cases used to create the discriminant analysis, 723 out of the 863 alumni ( 83.8 percent) who currently donate and plan to continue were classified correctly. More than 80 percent ( 80.4 percent) of the alumni who currently donate and plan to increase were classified correctly. Although overall only 56.3 percent of the cases were classified correctly, it is mostly because this model did not classify nondonors very well. For alumni donors who plan to continue donation or who plan to increase donation, 83.8 and 80.4 percent were classified correctly.

Classifications based on the cases used to create the model tend to be too "optimistic" in that their classification rate is inflated (Mickelson, 2002). The cross-validated section of Table 4 attempted to correct this. In cross-validation, each case was 
classified by the discriminant function derived from all cases other than that case. That is, each case was taken out of the discriminant analysis and the rest of the cases were used to classify this case into alumni groups. As the "Cross-validated\%" section suggested, 717 out of the 863 alumni $(83.1$ percent) who currently donate and plan to continue were classified correctly. More than 80 percent (81.2 percent) of the alumni who currently donate and plan to increase were classified correctly. The classification table and cross-validation tables show the overall reliability of this discriminant analysis in predicting alumni donors.

\section{Findings}

The study's results supported three of the four proposed hypotheses. The discriminant analysis supported hypotheses 1, 2, and 3; however, the analysis only partially supported hypothesis 4 . That is, while graduation year and gender are significant predictor variables of alumni donation, not all demographic variables were determined to be significant predictors.

The results confirmed the first research hypothesis: Student experience significantly influences alumni donations. The results indicated that satisfaction was greater among alumni who believed that the university contributed to their education, the student experience-impact on career factor. Satisfaction was also greater for those alumni who had developed relationships with university faculty and staff during their educational experiences. If alumni were satisfied with their previous student experiences, they were more inclined to give. This finding was consistent with Shadoian's (1989) and Oglesby's (1991) results in which they found that a significant difference existed between donors and nondonors on the predictor student experience.

The positive effect of alumni experience on alumni donation confirmed the second research hypothesis: alumni experience significantly distinguishes alumni donors from nondonors. Since alumni experiences are closely related to alumni marketing efforts such as parties, reunions, newsletters, and solicitations, the results confirm that these efforts do engage alumni, and that alumni may be more likely to donate than those less or not engaged. Miracle's (1977) and Grill's (1988) earlier results confirm the study's findings. Taylor and Martin (1995) also reached similar findings. Alumni involvement with the university was a significant predictor in the discriminant analysis models applied.

The study's findings supported the third hypothesis: alumni motivation significantly distinguishes alumni donors from nondonors. The important contribution of alumni motivation, or internal desires rooted deeply enough to induce a commitment to the alma mater, was confirmed by the study. The findings also suggested that alumni who were more informed about the university had more positive perceptions of it, were more aware of and linked with perceived institutional needs, and, therefore, were more likely to give than those not well informed.

The study's findings only partially supported the fourth hypothesis: Demographic variables (graduation year, gender, ethnicity, type of degree, 
in or out of state, and membership status) significantly distinguish alumni donors from nondonors. The demographic variables of graduation year and gender $(p=0.00)$ were the most significant distinctions between donors and nondonors. The ethnicity demographic variable $(p=>0.05)$ was a more significant factor than the degree types, in or out of state, and membership status demographic variables $(p=0.05)$ distinguishing donors from nondonors.

The findings suggest that the demographic variable graduation year, a proxy for alumni age, was the most significant predictor of alumni donation. Previous researchers (Beeler, 1982; Lindahl and Winship, 1992; Okunade et al., 1994) also found support for similar variables. Olsen et al. (1989) found that the growth rate of donation coincided with the age-income profile of donors. The annual fund-raising model at the Northwestern University (Okunade and Berl, 1997) found that the "year after graduation" was a significant predictor of alumni giving.

Critical to this analysis was the Wilk's Lambda coefficient. Graduation year had the lowest Wilk's Lambda coefficient $(\lambda=0.856)$ in the test of equality of group means, which suggested that the graduation year variable had the greatest predictive power in the study's model. This finding also suggested a more prominent role for age as a proxy to graduation year than prior research revealed. Moreover, it supported the generalization that older alumni have higher net worth and larger capacity for charitable giving. Younger alumni, on the other hand, with less income and possible student loan debt, may be less generous to their alma maters than they otherwise might be.

\section{Implications}

Based on the study's findings, higher education administrators and alumni fundraisers can begin taking steps individually and collaboratively to improve alumni fund-raising results. The key to fund-raising success, however, will be contingent on increasing collaborative, not isolated, efforts.

\section{Comprehensive communication strategy}

A comprehensive communication strategy targeting past, current, and future students as potential donors is paramount in increasing alumni donations. Administrators should lead the way of keeping the horizon in sight while focusing on institutional needs today. The study's results suggest that the institution would benefit from this approach (Pearson, 1999).

In order to implement a multiple focus vision of fund raising, administrators will benefit from inviting to the table important internal stakeholders, especially alumni fundraisers, in designing and executing targeted communication efforts. A well-articulated communication plan will create more focused, interlocked, and cost-effective endeavors to increase alumni gift giving.

One outcome of successfully implementing a comprehensive communication strategy to expand alumni giving is budget increases for the alumni association and other units. Administrators should be open to this necessary change. The study's results suggest a need for higher education 
institutions to evaluate the current expenditure priorities. Historical trends indicate that institutions have increased expenditures in areas that do not have a significant impact on student experience and alumni satisfaction (Clotfelter, 1999). The benefits of increased future donations will far outweigh the cost of today's redirected and refocused expenditures.

\section{Current future funders}

Administrators may want to consider concentrating on the current undergraduate students as "future funders" for the institution. Providing these students with quality, wellrounded educational and extracurricular experiences will benefit the institutions in the end since the majority of alumni donations come from donors who give to their undergraduate alma mater (Council for Aid to Education, 2007).

In developing quality student experiences, administrators need to include alumni fundraisers in discussions on how best to enhance academic improvement, student extracurricular activities, and career counseling. Prioritized expenditures in these improvements will ensure enhanced student experiences while selected strategies will have the biggest impact not only on student experiences but also on cultivating donations for the future. The findings of this study suggest, and supported by similar recommendations from Oglesby (1991), that fund-raising efforts can be more successful when student affairs, the alumni association, university communications, and foundations are collaborating and working closely with one another.

\section{Relationship-building efforts}

Administrators can create a culture of valuing relationships between faculty and students during their time at the institution and after. Provide opportunities for faculty to mentor students beyond graduation. Support faculty and departments in reaching out to graduates by inviting their input on academic program improvements. Encourage departments to keep in touch with graduates through print and electronic communications. Offer technological assistance in maintaining and updating department websites listing graduates' professional accomplishments beyond graduation. Most importantly, provide departments the additional resources to implement these endeavors. Administrators who establish relationship building with students as a priority throughout the institution may see future financial benefits of increased donations.

\section{Enhanced alumni services}

The findings of the study confirm previous research. Satisfied alumni are more likely to remain engaged with the university than those not satisfied.

Engaged alumni are more likely to remain informed about the university than those not engaged. Informed alumni are more likely to understand the needs of the university and may be more likely to give than those less informed (Pearson, 1999). Alumni fundraisers who concentrate on improving the alumni experience, which most likely will influence alumni motivation, are more successful.

It may be fruitful for alumni fundraisers to evaluate current alumni programs to determine cost effectiveness and return on efforts. 
Secondly, fundraisers might consider hosting focus groups, conducting surveys, and soliciting input from alumni stakeholders on identifying their needs and satisfaction. If alumni are satisfied with alumni services, they are more inclined to give than those not satisfied (Pearson, 1999).

\section{Demographic variables to pursue}

The most significant predictor of alumni donations, according to the study's findings, is graduation year, with age as a proxy. This may signal an increased focus on older alumni. The baby-boom generation is coming into their own acquired wealth from investments or through inheritances. Typical of that generation, they are still looking for ways to impact society. It may seem counter-intuitive not to spend as much effort on newly graduated alumni; however, older alumni are established professionally and more financially secure. Alumni fundraisers would likely realize increased donations if they expanded and redirected solicitation budgets to tap into older alumni. Based on this study, they are more likely to donate than any other alumni group.

Another significant demographic variable to predict alumni donations is gender, which is noteworthy for future fund-raising strategies. Women tend to donate more often than men do, according to the study's findings. Coupled with the graduation year factor, the largest potential source for significant giving are older women. Women live longer than men live and inherit 70 percent of all estates. They are expected to own half the wealth in the United States by 2010 (Strout, 2007b). Alumni fundraisers should take heed of these statistics and redirect their alumni focus. Iowa State University did and the results look promising. Since 2000, the number of Iowa State female donors has increased by 37 percent because of Iowa State's redirected efforts and the amount of money donated increased 138 percent (Strout, 2007b). Alumni associations with limited budgets could focus on alumni age and gender, coupled with enhanced alumni services, and see significantly increased donations as a result.

\section{Conclusion}

The study's findings may interest fundraising officials in the efficient choice of prospective donors. Alumni-specific data collected through the survey can be used with this model to predict individuals' propensity to give. Alumni fundraisers could use this model to predict the likelihood of giving for each alumnus/a. For this study, the model predicted donors correctly 81 percent of the time. Fundraisers may want to use this model to predict the propensity to give and spend more resources on those alumni more likely to give. A major factor is that the survey instrument is reliable and readily available.

More research to fully test the alumni donation model proposed and the contribution of each significant predictor is needed. The criterion variable in this study was classified as a categorical variable, and as such, can only predict the membership of donor and nondonor status. If donation amount was available as a continuous variable, it could serve as a predictor variable in a multiple-regression analysis. Such an analysis would 
directly assess the contribution of each predictor to that contribution, which would provide more comprehensive information than can the analysis required in this study.

The model introduced in this study may provide an alumni association a basis for investigating more complex linkages between alumni and their donation behaviors. Such research may require greater integration of a larger database, including alumni income level and alumni donation amount. These issues, along with accompanying research and methodological issues, pose a challenge to improving a deeper understanding of the relationship between alumni and their donations.

\section{Note}

${ }^{1}$ This manuscript is based on X. Sun (2005), “A multivariate causal model of alumni giving at a Midwest public university," unpublished doctoral dissertation, University of NebraskaLincoln.

\section{References}

Andreoni, J. (1989), "Giving with impure altruism: Applications to charity and Ricardian equivalence," Journal of Political Economy, 97, pp. 1447-1458.

Andreoni, J. (1990), "Impure altruism and donations to public goods: A theory of warmglow giving," The Economic Journal, 100, pp. 464-467.

Bar-Tal, D. (1976), Prosocial Behavior: Theory and Research, Halsted Press, New York.

Becker, G.S. (1974), “A theory of social interaction," Journal of Political Economy, 82, pp. 1063-1093.

Beeler, K.J. (1982), "A study of predictors on alumni philanthropy in private universities," unpublished doctoral dissertation, University of Connecticut.

Belfield, C.R. and Beney, A.P. (2000), "What determines alumni generosity? Evidence for the UK," Education Economics, 18, pp. 65-80.
Blumer, H. (1969), Symbolic Interactionism: Perspective and Method, Prentice-Hall, Englewood Cliffs, NJ.

Bristol Jr., R. (1990), "The life cycle of alumni donations," The Review of Higher Education, 13, pp. 503-518.

Bruggink, T.H. and Siddiqui, K. (1995), “An econometric model of alumni giving: A case study for a liberal arts college," The American Economist, 39, pp. 53-61.

Burt Jr., W.W. (1989), “Alumni donors and nondonors of Southeast Missouri State University according to institutional involvement, educational satisfaction and demographic characteristics," unpublished doctoral dissertation, University of California, Los Angeles.

Clotfelter, C.T. (1999), “The familiar but curious economics of higher education: Introduction to a symposium," Journal of Economics Perspective, 13, pp. 3-12.

Clotfelter, C.T. (2003), "Alumni giving to elite private colleges and universities," Economics of Education Review, 22, pp. 109-120.

Coelho, P.R.P. (1985), “An examination into the causes of economic growth: Status as an economic good," Research in Law and Economics, 7, pp. 89-116.

Council for Aid to Education (2007), "Voluntary support for education." [Internet], available from 〈www.cae.org (Accessed October 20, 2007).

Foa, U.G. and Foa, E.B. (1974), Societal Structures of the Minds, Thomas, Springfield, IL.

Gardner, P.M. (1975), "A study of the attitudes of Harding College alumni with an emphasis on donor and non-donor characteristics," unpublished doctoral dissertation, Ohio University.

Graham, A.E. and Husted, T.A. (1993), "Understanding state variations in SAT scores," Economics of Education Review, 12, pp. 197-202.

Grill, A.J. (1988), “An analysis of the relationships of selected variables to financial support provided by alumni of a public university," unpublished doctoral dissertation, Ohio University.

Grimes, P.W. and Chressanthis, G.A. (1994), "Alumni contributions to academics: The role of intercollegiate sports and NCAA sanctions," American Journal of Economics and Sociology, 53, pp. 27-40.

Halfpenny, P. (1999), "Economic and sociological theories of individual charitable giving: Complementary or contradictory," Voluntas: International Journal of Voluntary and Nonprofit Organizations, 10, pp. 197-215.

Harrison, W.B. (1995), "College relations and fundraising expenditures: Influencing the probability of alumni giving to higher education," Economics of Education Review, 14, pp. 73-84. 
Hueston, F.R. (1992), "Predicting alumni giving: A donor analysis test," Fund Raising Management, July, pp. 19-22.

Kleinginna, P. and Kleinginna, A. (1981), "A categorized list of motivation definitions, with suggestions for a consensual definition," Motivation and Emotion, 5, pp. 263-291.

Leslie, L.L., Drachman, S.S., Ramey, G.W. and Conrad, C.F. (1983), "Factors accounting for variations over time in voluntary support for colleges and universities," Journal of Educational Finance, 9, pp. 213-215.

Lindahl, W.E. and Winship, C. (1992), "Predictive models for annual fundraising and major gift fundraising," Nonprofit Management and Leadership, 3, pp. 3-64.

Mael, F. and Ashforth, B.E. (1992), “Alumni and their alma mater: A partial test of the reformulated model of organizational identification," Journal of Organizational Behavior, 13, pp. 103-123.

Mickelson, J. (2002), "Multivariate statistics," unpublished manuscript, University of NebraskaLincoln.

Miracle, W.D. (1977), "Differences between givers and non-givers to the University of Georgia annual fund," unpublished doctoral dissertation, University of Georgia.

Oglesby, R.A. (1991), “Age, student involvement, and other characteristics of alumni donors and alumni non-donors of Southwest Baptist University," unpublished doctoral dissertation, University of Missouri.

Olsen, K., Smith, A.L. and Wunnava, P.V. (1989), "An empirical study of the life-cycle hypothesis with respect to alumni donations," American Economists, 33, pp. 60-63.

Okunade, A.A. and Berl, R.L. (1997), "Determinants of charitable giving of business school alumni," Research in Higher Education, 38, pp. 201-214.

Okunade, A.A., Wunnava, P.V. and Walsh, J.R (1994), "Charitable giving of alumni: Microdata evidence from a large public university," American Journal of Economics and Sociology, 53, pp. 73-84.

Pearson, J. (1999), "Comprehensive research on alumni relationships: Four years of market research at Stanford University," New Directions for Institutional Research, 101, pp. 5-21.

Shadoian, H.L. (1989), "A study of predictors of alumni in public colleges," unpublished doctoral dissertation, University of Connecticut.

Steinberg, R. (1997), "Overall evaluation of economic theories," Voluntas: International Journal of Voluntary and Nonprofit Organizations, 8, pp. 179-204.

Stevens, J.P. (2002), Applied Multivariate Statistics for the Social Sciences, Lawrence Erlbaum Associates, Mahwah, NJ.

Strout, E. (2007a), "Donations increase for 3rd year in a row," The Chronicle in Higher Education, [Internet]. March 2, p. A1, available from: www.chronicle.com (accessed October 23, 2007).

Strout, E. (2007b), "Courting female doners," The Chronicle of Higher Education, [Internet], July 6, pp. A21, available from www.chronicle.com (accessed October 23, 2007).

Sugden, R. (1984), "Reciprocity: The supply of public goods through voluntary contribution," Economic Journal, 94, pp. 772-787.

Taylor, A.L. and Martin Jr., J.C. (1995), "Characteristics of alumni donors and nondonors at a research I, pubic university," Research in Higher Education, 36, pp. 283-298.

Thibaut, J.W. and Kelley, H.H. (1959), The Social Psychology of Groups, John Wiley \& Sons, New York.

Walster, E. and Walster, G.W. (1978), Equity: Theory and Research, Allyn and Bacon, Boston.

Weintraub, E.R. (1985), General Equilibrium Theory, Cambridge University Press, Cambridge, MA.

Winston, G. (1999), "For-profit education: Godzilla or Chicken Little," Change Magazine, 31, pp. 13-19.

Wolverton, B. (2007), "Growth in sports gifts may mean fewer academic donations," The Chronicle of Higher Education [Internet], October 5, p. A1, available from: (www.chronicle.com (accessed October 23, 2007).

Yoo, Y.H. and Harrison, W.B. (1989), "Altruism in the market for giving and receiving: A case of higher education," Economics of Education Review, 8, pp. 367-379. 